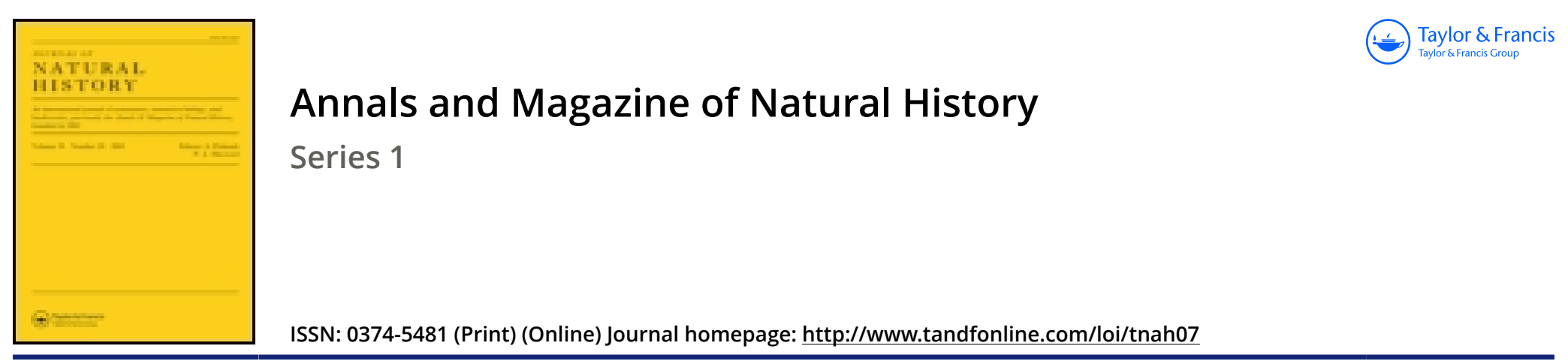

\title{
III.—On the British Desmidieæ
}

John Ralfs Esq. M.R.C.S.

To cite this article: John Ralfs Esq. M.R.C.S. (1845) III._-On the British Desmidieæ, Annals and Magazine of Natural History, 16:102, 10-15, DOI: 10.1080/037454809494525

To link to this article: http://dx.doi.org/10.1080/037454809494525

册Published online: 14 Dec 2009.

Submit your article to this journal

Q View related articles ¿ 
the oral appendages. That it is a member of the Aphroditacea no one can doubt, although it possesses few of the technical characters by which that family has been hitherto defined. It has no near ally in the family. In common with the Palmyre, the back is naked or destitute of scales; but there is nothing else in which the two genera agree.

Plate II. fig. 7. Spinther oniscoides of the natural size. Fig. 8 . The dorsal aspect viewed through a common magnifier. Fig. 9. A view of the ventral surface. Fig. 10. Two feet detached and viewed from the back. Fig. 11. A foot as seen from below. Figs. 12, 13, 14. The bristles.

[To be continued.]

III.-On the British Desmidieæ. By John RaLrs, Esq., M.R.C.S., Penzance*.

[With a Plate.]

Didymoprium, Kütz.

Filaments elongated, gelatinous, fragile, cylindrical or subcylindrical, with a bidentate process or angle on each side of the joints.

The filaments are elongated, simple, jointed, gelatinous and very fragile, and finally separate into single joints; each joint has two opposite, bidentate angles or processes. Hence the margins of the filaments are crenate, and as it is regularly twisted it not only appears of unequal breadth, but the form of its joints also varies as more or less of the angles is seen at the margin; in short, as they are at one time fully visible and at length entirely disappear.

For synonyms, habitats, and description of the species, I must refer to my former article on Desmidium.

1. D. cylindricum, Ktz. Filaments subcompressed, inclosed in a distinct mucous sheath; joints broad as long. Kütz. Phy. Gen. p. 165. Desmidium cylindricum, Annals of Nat. Hist. vol. xi. p. 373. pl. 8. fig. 1; Menegh. l. c. p. 204.

Plate III. fig. 4. Didymoprium cylindricum, joint dividing into two.

2. D. Borreri. Filaments cylindrical, not inclosed in a sheath ; joints inflated, twice as long as broad. Desmidium Borreri, Annals of Nat. Hist. vol. xi. p. 375. pl. 8. fig. 4.

Additional habitats. Ashdown Forest and near Battle, Sussex, Mr. Jenner; Ireland, Mr. Andrews.

Plate III. fig. 5. Didymoprium Borreri, joints dividing.

GL/EOPnium, Berk. (in lit.)

Filaments elongated, simple, cylindrical, very gelatinous; joints

* Read before the Botanical Society of Edinburgh, July 11, 1844. 
Ann.\&.Mag. Nat. Hist. Vol.16 PI. III.

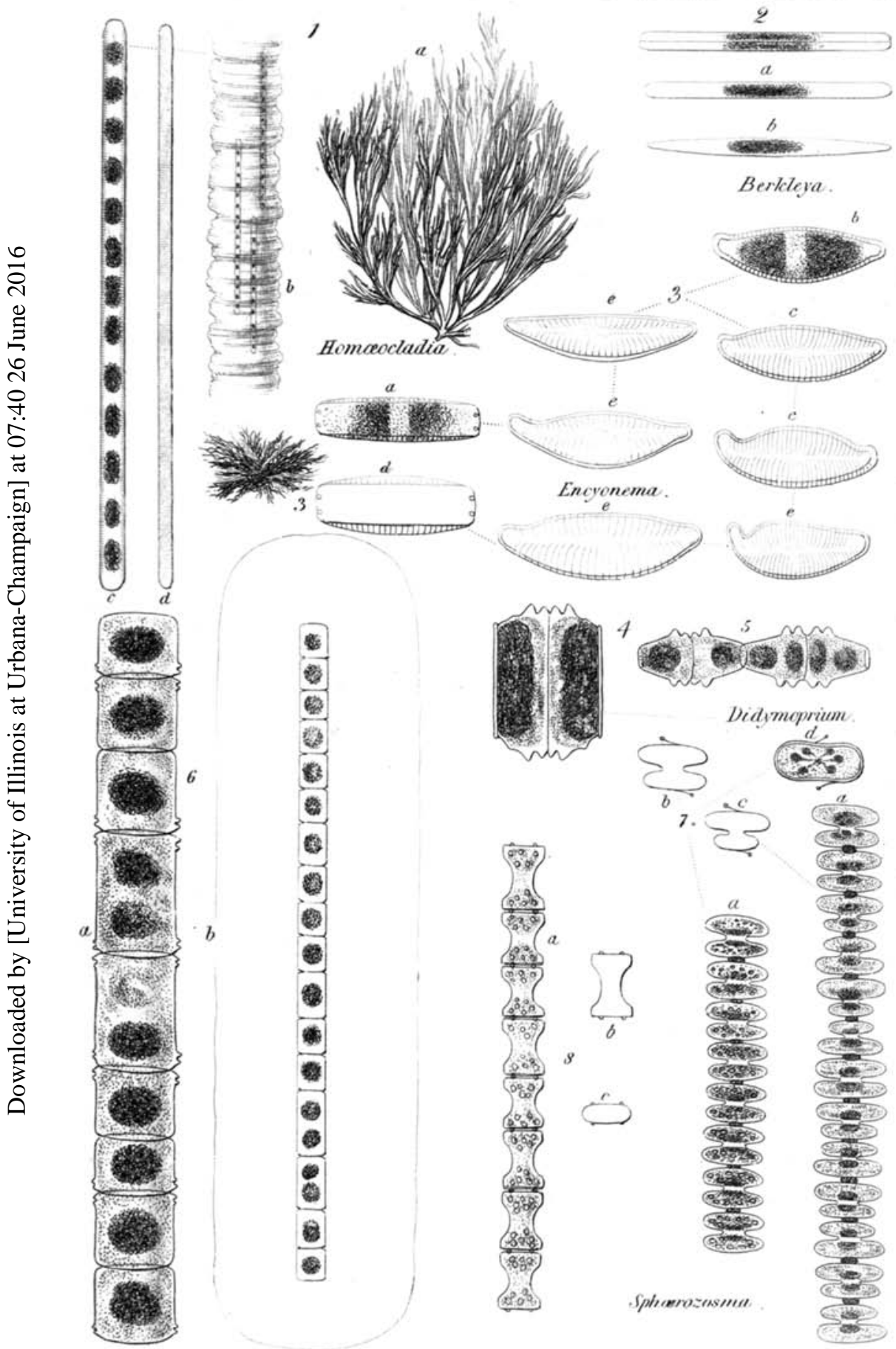

Glcoprium .

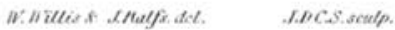


with either a slight constriction which produces a crenate appearance, or a grooved rim at one end which forms a bifid projection on each side.

The filaments are cylindrical, simple, jointed, invested with a broad gelatinous sheath, and very fragile in one species, but not so in the other. Either a groove passes round each joint, giving a crenate appearance to the margins of the filament, and dividing the endochrome into two portions, or else a grooved rim at one extremity of the joint appears on each side like a bifid process.

A transverse view shows a radiate endochrome in one species, but in the other I was unable to obtain this view on account of its want of fragility.

The cylindrical filaments distinguish this genus from Desmidium and Sphcerozosma. From Didymoprium it differs in the absence of angular projections, in not being twisted, and in always having the same apparent breadth.

1. G. dissiliens. Filaments fragile, crenate; a shallow groove round each joint divides the endochrome into two portions. Desmidium mucosum, Breb. Alg. Fal. p. 65. pl. 11; Menegh. Synop. Desmid. in Linnæa 1840, p. 204 ; Ralfs in Annals of Nat. Hist. vol. xi. p. 374. pl. 8. fig. 2 .

This plant is apparently common, as, in addition to the habitats already given, Mr. Jenner has gathered it in numerous stations both in Sussex and in Kent. It has also been gathered in Ireland, near Bandon, by Dr. Allman, and in Kerry by Mr. Andrews.

In an advanced state it becomes of a pale opake green.

The mucous sheath is easily perceived, and is on each side of the filament as broad as the central coloured portion. The endochrome is divided into two portions by the central constriction, which can always be detected on a careful examination with the higher powers of the microscope.

This plant has been involved in much confusion; it was by mistake figured in 'Eng. Bot.' for the Conferva dissiliens of Dillwyn, and afterwards altogether omitted in Hooker's 'Br. Flora' and in Harvey's ' Manual of the British Algæ.' From the synonyms in Meneghini's 'Synopsis Desmidiearum,' it seems that De Brébisson considered it the Conferva mucosa of Mertens and Dillwyn.

2. G. mucosum. Filaments scarcely fragile; joints not constricted, but having at one of the ends a minute bidentate projection on each margin, the adjoining end of the next joint bearing similar projections. Conf. mucosa, Mert. ; Dillw. Brit.Conf. tab. B. ; Hook. Br. Fl. vol. xi. p. 351 ; Harv. Br. Alg. p. 127. Gloeotila moniliformis, Kütz. Phyc. Generalis, p. 245 ?

In shallow pools and gently-flowing streams, probably not uncom- 
mon. Most plentiful in the autumn. Bantry, Miss Hutchins ; Appin, Capt. Carmichael. Trentishoe, Devonshire; Penzance and Dolgelley, $J . R$. ; Cheshunt, Mr. Hassall; Chiltington Common near Pulborough, Sussex; and in the peat bog at Fisher's Castle near Tunbridge Wells, Mr. Jenner.

Filaments elongated, very gelatinous, of a pale translucent green, not fragile. Under the microscope the joints are generally about equal in length and breadth, and the endochrome forms a single irregular patch. The joints are not constricted, but at one end they have on each margin a minute bidentate projection: as the similar ones of the next joint are at its adjoining extremity, these projections occur only near the alternate dissepiments. When, however, the joint is elongated, preparatory to the formation of two joints, the endochrome is divided into two portions, and then these processes are present at both ends, the next joint undergoing a similar change. These projections are extremely minute, and can only be detected by employing the highest power of the microscope, and even then are liable to be overlooked if not carefully sought for.

I examined many specimens of this plant in 1841 , but did not perceive these curious projections until the following year. I believe they are really formed by a grooved rim round the end of the joint, because however the filament may be moved they are equally apparent; whereas if they were processes, as in Didymoprium, they would be sometimes either entirely concealed or rendered less apparent.

The filaments have a very broad mucous sheath, which from its great breadth and absence of colour is not easily discemed; it is more evident when a specimen is dried on talc or glass, as the margins are then generally perceptible. When gathered the filaments are very distinct, frequently parallel and subdistant even to the naked eye : this depends on the great breadth of their mucous sheaths, which prevent the coloured filaments coming into contact. By this character G. mucosum may in general be known even without the aid of a microscope. The same circumstance occurs in young plants of $G$. dissiliens, but is less remarkable, as its mucous sheath is not more than half as broad.

Under a low power of the microscope G. mucosum has considerable resemblance to G. dissiliens, with which it is probably not unfrequently corfounded. But they may always be distinguished even without the aid of the microscope. The G. dissiliens is extremely fragile, and will break into pieces if a small portion be placed on the hand and the finger gently passed over it; this plant, on the contrary, will not break if it be taken out of the water and allowed to hang down in long strings. It always has a clear translucent appearance; the $G$, dissiliens, except when very young, 
is of an opake green. The latter if kept in water for a few days spontaneously separates into fragments ; G. mucosum, although treated in the same manner for weeks, has not separated into fragments sufficiently small to enable me to obtain a transverse view. I am therefore unable to say whether the endochrome in that aspect appears stellate, as in G. dissiliens.

Under the microscope G. mucosum may be known by the joints not appearing crenate and by the endochrome being in a single pateh, or if divided, the joints are longer than in G. dissiliens. Its mucous sheath is with difficulty detected, and when seen will be found to extend on each side twice the breadth of the coloured filament; whereas in G. dissiliens the mucous sheath is, except in old specimens, detected without difficulty.

This is a remarkable plant, and differs in many respects from the other Desmidiea; indeed so much so, that I had some doubts whether it would be correctly placed in this family; but as the Rev. M. J. Berkeley, as well as every other algological friend whose opinion I solicited, considers that its place must be in the same genus with the preceding species, I have described it here.

The joints seem to be in pairs, and a single one is consequently unsymmetrical.

G. mucosum agrees with the other Desmidiece in its capability of being kept a long time without undergoing decomposition.

I was indebted to $\mathrm{Mr}$. Hassall for the information that the plant under consideration was the Conferva mucosa, Dillw., as also for an opportunity of examining a foreign specimen under that name from the herbarium of Dr. Greville.

$I$ have since been able to compare our plant with a portion of an Irish specimen of Conferva mucosa presented to me by Mr. Borrer, who received it from $\operatorname{Sir}$ W. J. Hooker. From the latter I learn that this was an original specimen from Miss Hutchins. Sir W. J. Hooker has also presented me with an Appin specimen collected by Capt. Carmichael. All these are identical with the present plant.

Puate III. fig. 6. Glaoprium mucosum : a, portion of a flament much magnified to show the bifid projections; $b$, less magnified to show the breadth of the sheath.

\section{Sphenozosma, Corda.}

Filaments gelatinous, plane, fragile; joints closely united by means of glandular processes, and deeply divided on each side, thus forming two segments and giving a pinnatifid appearance to the filament.

The filaments are pale green, gelatinous, simple, plane, have a pinnatifid appearance from the division of the joints into two segments, are fragile, and finally separate into single joints. I 
have not observed that the filaments are twisted, as in Desmidium and Didymoprium. At the junction of the joints there are on each margin one or two minute glands or processes which are scarcely discernible in the front view, and do not interfere with the close junction of the joints. The transverse view is linear or oblong, and the processes, one or two at each side, are much more evident than in the front view.

is This genus differs from Desmidium, Didymoprium and Glaoprium in its flat filaments (which are not twisted), in the deep division of the joints into segments, and especially in the presence of the minute gland-like processes at the junction of the joints. From the Odontella of Ehrenberg it may be known by the joints being united along their entire breadth, whereas in Odontella they are connected only by the elongated angles which inclose a small vacant space between them.

On account of its deeply constricted joints, this genus forms a connecting link between the three preceding genera and Staurastrum.

In Spharozosma, as in the other genera with deeply constricted cells, the segments are frequently unequal during the growth of the plant, and they become in like manner equal when it approaches maturity and its joints no longer divide.

1. S. unidentata. Joints as broad as long, divided into two segments by a linear notch on each side; junction-glands stalked, oblique, solitary at the centre of each margin. Odontella unidentata, Ehr. Infus. p. 159 ; Pritch. Infus. p. 191. Desmidium compressum, Annals of Nat. Hist. vol. ix. p. 253. Isthmia vertebrata, Menegh. l. c. p. 205 ?

This plant has been gathered at Rotherfield and near Tunbridge Wells by Mr. Jenner since the publication of my former notice of it. I then considered it an undescribed species of Desmidium. I have since been favoured by $\mathrm{Mr}$. Berkeley with the following extract from Ehrenberg's observations on the Odontella unidentata:-"This species is surprising by reason of its evolution. There are always two great and two small joints alternately turned to one another, and the processes are found alternately between the small and large joints. This reminds one of Scenedesmus convergens and the Euastra." This extract leaves no doubt that Ehrenberg's Odontella unidentata is identical with the plant I described under the name of Desmidium compressum. He correctly points out the affinity between the joints in this plant and the frond in Euastrum. As in both genera be considers the segments of the cell to be distinct joints, he has described the process or junction-gland in the present plant as occurring at every alternate dissepiment. But his description of the 
alternate occurrence of two small and two large segments is incorrect, for although the smaller segments are necessarily in pairs, being formed during the elongation and bisection of the cells, $\mathbf{I}$ have never seen all the joints thus dividing at the same time, which must always happen if his statement be correct; on the contrary, many joints with equal segments will often succeed each other, here and there followed by the unequal segments, as I have described above. When the reproductive granules are perfected and the filament of the mature plant ceases to elongate, all the joints will be found similar and their segments equal.

In my former notice of this plant I described it as destitute of a mucous sheath; I have not gathered it since; but on further consideration I believe that the sheath exists, although I failed to detect it. The reason for coming to this conclusion is, that the filaments when gathered were remarkably distinct and parallel, exactly as those in Glaoprium mucosum; I have no doubt that in both this appearance is an effect of the same cause, and that broad colourless sheaths separate the coloured filaments. I suppose therefore its tenuity, want of colour and great breadth prevented its observation.

Plate III. fig. 7. Spharozosma unidentata : a, portions of filaments; $b$, front view of an empty joint ; $c$, joint with one of its segments newly formed; $d$, transverse view.

2. S. excavata. Joints longer than broad, with a deep excavation on each side, and two sessile glands on each margin at their junction.

Pools, Dolgelley and Penzance, $J$. R.; Cross-in-Hand, and Ashdown Forest, Sussex, and bogs at Fisher's Castle, Kent, Mr. Jenner.

Very minute, seldom more than twenty joints in the filament, which is fragile, and finally separates into single joints; at their junction, in the front view, are two minute processes or glands invisible before the escape of the endochrome, and situated one near each angle. The joints are from one and a half time to twice as long as broad, much constricted in the middle ; the constriction is like an excavation or broad sinus on each side, so that the margins of the filament appear sinuated. The transverse view is oblong with four sessile minute glands, two on each side and situated near their ends.

The endochrome is pale bluish green with minute scattered granules.

Plate III. fig. 8. Spharozosma excavata: $a$, portion of a filament; $b$, front view of an empty joint; $c$, transverse view. 